Essays of an Information Scientist: Creativity, Delayed Recognition, and other Essays, Vol:12, p.201, 1989 Current Contents, \#30, p.3-13, July 24,1989

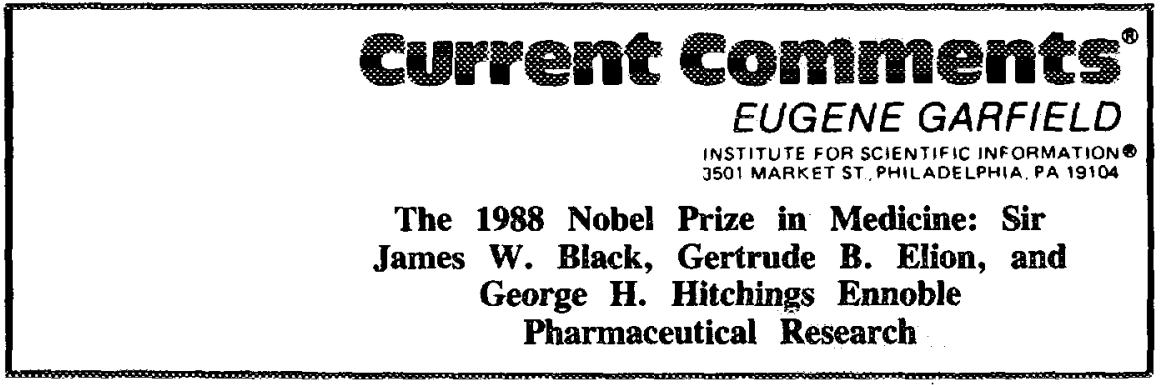

Number 30

july 24,1989

The work of the three Nobel laureates is examined. Their development of highly successful drugs was influenced by a keen understanding of basic biochemical processes and of the concept of selectivity. In addition to presenting brief biographical sketches of the laureates, the essay considers their most-cited papers and examines how this work has been reflected in ISI ${ }^{\oplus}$ research fronts.

The Nobel Assembly of the Karolinska Institute, Stockholm, Sweden, awarded the 1988 Nobel Prize in physiology or medicine jointly to Sir James W. Black, King's College Hospital Medical School, London, UK, and Gertrude B. Elion and George H. Hitchings, scientists emeriti, Wellcome Research Laboratories, Research Triangle Park, North Carolina. They were honored for their discoveries of "important principles for drug treatment."'1

In characterizing their award-winning work, the Nobel Assembly noted that they developed drugs that have proved essential in the treatment of a number of disorders. However, their work has an even larger significance: "While drug development had earlier mainly been built on chemical modification of natural products they introduced a more rational approach based on the understanding of basic biochemical and physiological processes." It is also significant that the three recipients were not academics, as are most Nobel laureates. ${ }^{2}$ Most of their work was done in the pharmaceutical industry.

The last Nobelists honored for work of pharmaceutical significance were Sune K. Bergström and Bengt I. Samuelsson, both of the Karolinska Institute, and John R. Vane, William Harvey Research Institute, St. Bartholomew's Hospital Medical College, London, in 1982, for discoveries concerning prostaglandins and related biologi- cally active substances. ${ }^{3}$ Before them, Daniel Bovet was recognized in 1957 for his work on antihistamines. Because histamine had no naturally occurring antidote, Bovet's goal was to find a substance that could counter the effects of free histamines. Three thousand experiments later, he had discovered the structural basis of most of the antihistamines available today. ${ }^{4}$

\section{Black's Work}

Black was recognized for his understanding of physiological mechanisms and his attention to the cell surface. Indeed, his two major drug discoveries were based on a better understanding of cell-surface receptors. "Receptors"' are sites or structures on surfaces of cells to which molecules bind, giving rise to some biological response. "Blockers" prevent receptors from triggering an unwanted reaction, such as a rise in blood pressure or heart rate or the release of histamine.

Black helped design the first clinically important beta blocker, propranolol hydrochloride, a drug that inhibits the excitatory effect on the heart of epinephrine and norepinephrine, also known as adrenaline and noradrenaline. He based his work on some earlier suggestions by the late R.P. Ahlquist, 5 Medical College of Georgia, Augusta, who noted that the physiological effects of the hormone adrenaline were mediated 


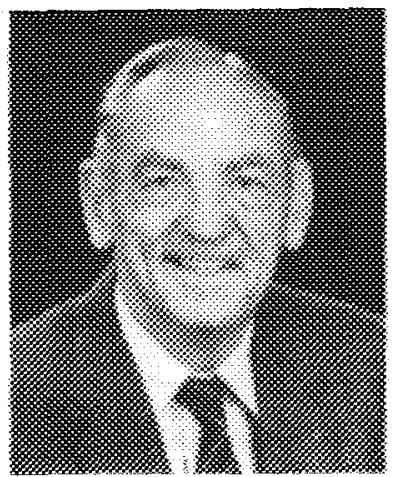

George H. Hirchings

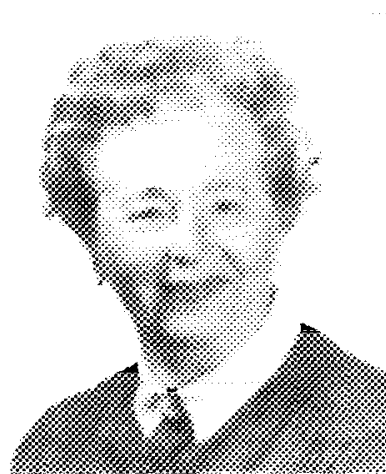

Gertrude B. Elion

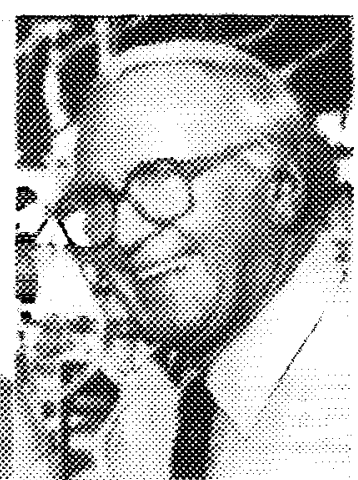

Sir James W. Black by two classes of receptors, alpha and beta. Black set out to synthesize a drug that would block the beta receptors. "Beta blockers" lock into the receptor sites, thus preventing the usual excitatory action of the hormone receptors and in effect relaxing the heart muscle so that its demand for oxygen does not exceed the supply.

Developed in 1964 under the brand name Inderal, propranolol hydrochloride has been effective in treating a host of heart disorders: angina pectoris, high blood pressure, abnormal heart rhythm, as well as migraine. It has also been found to reduce the mortality rate from heart attacks.

The other major breakthrough for which Black was recognized came in the process of synthesizing substances that block histamine receptor $\left(\mathrm{H}_{2}\right)$ mediated effects, work that he performed at Smith Kline \& French (SK\&F), now SmithKline Beckman Corporation, Welwyn Garden City, Hertfordshire, UK. As Black himself noted in his Nobel lecture, "The histamine project was started by analogy with my experience of the adrenaline project."6 In other words, he set out to apply to histamine receptors the approach that had produced beta blockers.

At the outset of his search for an antiulcer drug, Black was aware that (a) excessive secretion of gastric juices causes ulcers, (b) these secretions are stimulated by the chemical mediator histamine, which is also released during hay fever and other allergic reactions, and (c) antihistaminics would not cure ulcers. From these facts, he inferred that histamine produces reactions in the body by binding to one of two very different molecular receptors. One receptor is found on cells lining the respiratory passages ( $\mathrm{H}_{1}$-receptor); the other, on cells lining the gut wall $\left(\mathrm{H}_{2}\right.$-receptor). Antiallergy drugs block only $\mathrm{H}_{1}$-receptors.

In 1972 Black and his coworkers formally characterized the histamine receptor in the stomach lining as different from that in the respiratory tract. ${ }^{7}$ By 1975 they had developed the antiulcer drug cimetidine, which has been widely and successfully marketed under the brand name Tagamet since 1977 . A 1980 essay devoted to ulcers and ulcer research, based in part on my own long and personal experience, noted the success of this drug and its impact on the literature. ${ }^{8}$ Based on his citation record, I was able to support Black's nomination for the John Scott Award in 1981.9

\section{Elion and Hitchings's Work}

Elion and Hitchings were honored for work they started and built on together since 1944. Even before Elion joined what Hitchings called his "department of one," 10 the senior biochemist had theorized that it should be possible to change the way cells grow by substituting slightly different compounds from those occurring naturally in the body. This introduction of false building blocks, substituting for certain basic substances, could interfere with the manufacture of deoxyribonucleic acid (DNA) and in- 
hibit the growth of unwanted cells. The key, as Hitchings and eventually Elion stressed in their research, was finding substances that would act selectively, affecting cancer cells, for example, but not normal cells.

The string of successful compounds and drugs that punctuated their 40-year collaboration may be said to have resulted from their investigations into DNA metabolism. They demonstrated that nucleic acid in normal human cells metabolized differently than in cancer cells, protozoa, bacteria, and viruses. They also identified antimetabolites in nucleic acid metabolism.

Of the many drugs that Elion and Hitchings discovered or helped in developing, the first to prove of lasting value in cancer therapy was 6-mercaptopurine, released under the Burroughs Wellcome brand name Purinethol. Building on several earlier drug trials (namely, diaminopurine and thioguanine), Elion synthesized the compound 6-mercaptopurine in 1951. After it was shown to inhibit tumor growth in animal tests, Joseph H. Burchenal, a colleague at the Sloan-Kettering Institute (now the Memorial Sloan-Kettering Cancer Center), New York, moved it into clinical trials on children with acute leukemia. Soon, the drug was being tested in several medical centers around the country. Immediately, Hitchings received hordes of letters requesting trial doses. Within days, the Food and Drug Administration (FDA) permitted commercial release of the drug-a sharp contrast to the FDA's drug approval process today.

As occurs so often in science, this discovery later lent itself to another, perhaps still more useful one. While mercaptopurine greatly prolonged the lives of children with leukemia, it did not stay active in the body long enough to be permanently effective. (It is still used as an antileukemic, but in combination with other drugs.) Together, Elion and Hitchings then produced azathioprine, a modified form of 6-mercaptopurine; it was the first immunosuppressive agent to allow successful organ transplants. Elion had spent six years analyzing the metabolism of mercaptopurine in humans before she synthesized azathioprine (brand name Imuran). Though it showed no better results against cancer than did mercaptopurine, Imuran was most effective in blocking the immune response that triggers rejection of foreign tissue. By 1962 it was being used, with great success, on human patients undergoing kidney transplants.

Yet another modified form of the natural purine hypoxanthine produced by Hitchings's laboratory in the 1950 s was allopurinol, an inhibitor of the enzyme xanthine oxidase, which is responsible for uric acid synthesis. Under the brand name Zyloprim, this drug turned out to be useful not only in preventing uric acid buildup in some cancer patients, but also in treating gout, which is characterized by uric acid deposits in the joints.

The principles Hitchings and Elion had formulated led also to the development of two important antiviral drugs: acyclovir (Zovirax), which effectively treats herpesvirus infections; and azidothymidine (AZT), or zidovudine (Retrovir), the only drug approved so far to combat some of the symptoms of AIDS.

Synthesis and antiviral testing of what was to become the antiherpes drug, acyclovir, was undertaken in the 1970 s by a team at Wellcome Research Laboratories. Howard J. Schaeffer, now Wellcome's vice president for research, and Lilia Beauchamp conducted the syntheses; D.J. Bauer and P. Collins the antiviral testing; 11 and the mechanisms of action were elucidated by Elion $e t$ al. in a highly cited paper published in 1977.12 Elion and her team wanted to learn how and why this compound worked and why it was so selective. What they discovered was that acyclovir remains inert until it meets the herpesvirus. The virus then converts the compound into a toxic substance, bringing about its own demise. The drug was released commercially in 1982 and has become Burroughs Wellcome's single most profitable product. ${ }^{13}$

The second antiviral drug, AZT, was also discovered as a result of Elion and Hitchings's standard research approach-namely, "to look for differences in nucleic acid metabolism between normal human cells, cancer cells, protozoa, bacteria and virus, which could be utilized to develop drugs that 
Table 1: Papers authored by J.W. Black and cited in the SCF . The papers are arranged in descending order, according to number of citations. $A=$ total number of citations. $B=$ bibliographic citation.

A

1,745 Black J W, Duncan W A M, Durant C J, Ganellin C R \& Parsons E M. Definition and antagonism of histamine $\mathbf{H}_{2}$-receptors. Nature 236:385-90, 1972.

608 Black J W \& Stephenson J S. Pharmacology of a new adrenergic beta-receptor blocking compound (nethalide). Lancet 2:311-4, 1962.

470 Black J W, Crowther A F, Shanks R G, Smith L H \& Dornhorst A C. A new adrenergic betareceptor antagonist. Lancet $1: 1080-1,1964$.

394 Hlack J W, Duncan W A M \& Shanks R G. Comparison of some properties of pronethalol and propranolol. Brit. J. Pharmacol. Chemother. 25:577-91, 1965.

Black J W, Duncan W A M, Emmett J C, Ganellin C R, Hesselbo T, Parsons M E \& Wyllie J H. Metiamide-an orally active histamine $\mathrm{H}_{2}$-receptor antagonist. Agent. Action. 3:133-7, 1973.

Black J W, Owen D A \& Parsons M E. An analysis of the depressor responses to histamine in the cat and dog: involvement of both $\mathrm{H}_{1}$ - and $\mathrm{H}_{2}$-receptors. Brit. J. Pharmacol. 54:319-24, 1975. development of metiamide, a new histamine $\mathrm{H}_{2}$-receptor antagonist. Nature 248:65-7, 1974.

selectively block the growth of cancer cells and of noxious organisms." 1

\section{Citation Data}

Tables 1 and 2 list the most-cited papers by the three Nobel pharmacologists. Heading the list in Table 1 is Black's 1972 paper from Nature, ${ }^{7}$ on his second major discovery: a histamine $\mathrm{H}_{2}$-receptor antagonist. The paper is "concerned with the classification and specific blockade of the receptors involved in mepyramine-insensitive, non- $\mathrm{H}_{1}$, histamine responses. "7 Black and coauthors at SK\&F concluded that, aside from blocking certain effects of histamine, burimamide, the $\mathrm{H}_{2}$-receptor antagonist, also inhibits pentagastrin-stimulated acid secretion. This paper, which figures strongly in a long string of research fronts (discussed later), was cited about 1,750 times in the Science Citation Index ${ }^{\circledR}\left(S C I^{\circ}\right)$ between 1972 and the present. Figure 1 shows this paper's citation record year-by-year.

Black's work has been discussed in numerous citation studies, as far back as 1974.14 Two of his papers identified in that study discussed discovery of the beta blockers. Those same two papers also show up in a subsequent survey of Citation Classics ${ }^{*}$ published in Lancet. ${ }^{15}$

Black's 1972 paper on histamine $\mathrm{H}_{2}$-receptors, mentioned above, was identified early on as a potential classic in a study of the 50 papers most cited from 1972 to 1975. 16 Less than a decade later it appeared among the most-cited 100 Citation Classics for 1961-1982.17 One section of that essay discussed 11 previous Nobel laureates who were also on the list. Not surprisingly, the list also identified other future Nobelists such as J. Karle (1985 winner in chemistry), US Naval Research Laboratory, Washington, DC, and R.B. Merrifield (1984 winner in chemistry), The Rockefeller University, New York.

Table 2 lists the most-cited papers by Elion and Hitchings. Topping the list is the 1977 paper on the now-famed antiherpetic compound, in which the authors noted its potent activity against herpes simplex virus type 1. Their report also stressed the drug's selectivity: "Inhibition of growth of the host

Figure 1: Year-by-year performance of the most-cited papers by the winners of the Nobel Prize in medicine. Broken line $=$ Elion G B et al. Proc. Nat. Acad. Sci. USA 74:5716-20, 1977. Solid line $=$ Black $J W$ et al. Nature 236:385-90, 1972. Dotted line=Bushby S R M \& Hitchings G H. Brit. J. Pharmacol. Chemother. 33:72-90, 1968.

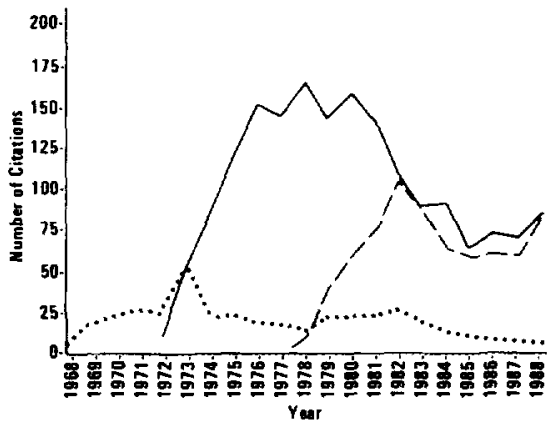


Table 2: Papers authored by G.B. Elion and/or G.H. Hitchings and cited in the SCP. The papers are arranged in descending order, according to number of citations. $A=$ total number of citations. $B=$ bibliographic citation.

$\mathbf{A}$

719 Elion G B, Furman P A, Fyfe J A, de Miranda P, Beauchamp L \& Schaeffer H J. Selectivity of action of an antiherpetic agent, 9-(2-hydroxyethoxymethyl)guanine. Proc. Nat. Acad. Sci. USA $74: 5716-20,1977$.

477 Schaeffer H J, Beauchamp L, de Miranda P, Elion G B, Bauer D J \& Collins P. 9-(2-hydroxyethoxymethyl)guanine activity against viruses of the herpes group. Nature 272:583-5, 1978 .

402 Bushby S R M \& Hitchings G H. Trimethoprim, a sulphonamide potentiator. Brit. J. Pharmacol. Chemother. 33:72-90, 1968.

307 Elion G B, Singer S \& Hitchings G H. Antagonists of nucleic acid derivatives. VIII. Synergism in combinations of biochemically related antimetabolites. J. Biol. Chem. 208:477-88, 1954.

292 Elion G B, Burgi E \& Hitchings G H. Studies on condensed pyrimidine systems. IX. The synthesis of some 6-substituted purines. J. Amer. Chem. Soc. 74:411-4, 1952.

275 Hitchings G H \& Burchall J J. Inhibition of folate biosynthesis and function as a basis for chemotherapy. Adv. Enzymol. Relat. Subj. Biochem. 27:417-68, 1965.

258 Burchall J J \& Hitchings G H. Inhibitor binding analysis of dihydrofolate-reductases from various species. Mol. Pharmacol. 1:126-36, 1965

240 Elion G B. Symposium on immunosuppressive drugs. Biochemistry and pharmacology of purine analogues. Fed. Proc. 26:898-904, 1967.

229 Fyfe J A, Keller P M, Furman P A, Miller R L \& Elion G B. Thymidine kinase from herpes simplex virus phosphorylates the new antiviral compound, 9-(2-hydroxyethoxymethyl)guanine. J. Biol. Chem. 253:8721-7, 1978.

215 Elion G B, Kovensky A \& Hitchings G H. Metabolic studies of allopurinol, an inhibitor of xanthine oxidase. Biochem. Pharmacol. 15:863-80, 1966.

207 Elion G B, Callahan S, Nathan H, Bieber S, Rundles R W \& Hitchings G H. Potentiation by inhibition of drug degradation: 6-substituted purines and xanthine oxidase. Biochem. Pharmacol. 12:85-93, 1963.

Hitchings G H \& Elion G B. Chemical suppression of immune response. Pharmacol. Rev. $15: 365-405,1963$.

172 Krenitsky T A, Papaioannou R \& Elion G B. Human hypoxanthine phosphoribosyltransferase. 1 Purification, properties, and specificity. J. Biol. Chem. 244:1263-70, 1969.

158 Nathan H C, Bieber S, Elion G B \& Hitchings G H. Detection of agents which interfere with the immune response. Proc. Soc. Exp. Biol. Med. 107:796-9, 1961.

155 Furman P A, St. Clair M H, Fyfe J A, Rideout J L, Keller P M \& Elion G B. Inhibition of herpes simplex virus-induced DNA polymerase activity and viral DNA replication by 9-(2-hydroxyethoxymethyl)guanine and its triphosphate. J. Virol. 32:72-7, 1979.

Massey V, Komai H, Palmer G \& Elion G B. On the mechanism of inactivation of xanthine oxidase by allopurinol and other pyrazolo[3,4-d]pyrimidines. J. Biol. Chem. 245:2837-44, 1970.

Elion G B, Bieber S \& Hitchings G $\mathbf{H}$. The fate of 6-mercaptopurine in mice. Ann. N. Y. Acad. Sci. 60:297-303, 1954.

124

Elion G B. Condensed pyrimidine systems. XXII. N-methylpurines. J. Org. Chem. 27:2478-91, 1962.

cell requires a 3000 -fold greater concentration of drug than does inhibition of viral multiplication."'12 This Citation Classic has averaged about 60 citations per year (see Figure 1).

Another paper worth noting is that coauthored by S.R.M. Bushby and G.H. Hitchings and published in the British Journal of Pharmacology and Chemotherapy in 1968. This most cited of Hitchings's papers reported on the antibacterial compound trimethoprim, which is still in use today in the treatment of bacterial infections. As described by the authors, the effectiveness of sulfonamides (or sulfa drugs) can be ex- tended through the use of trimethoprim, an inhibitor of bacterial folate reductases. 18

Although, as the papers listed in Table 2 demonstrate, Elion and Hitchings have not always appeared as coauthors, they have in fact always worked in unison, as accounts by them and their coworkers (in a later section) will show.

Elion and Hitchings have not shown up on our previously published lists of mostcited papers. A variety of factors, in no way related to the significance of their work, account for this. The 1977 paper by Elion is a case in point. I have often said that it would be desirable to review the most-cited paper 
list year-by-year. In the first few years this paper was cited well above the average, but it wasn't until the fifth year when citations reached a critical mass.

The 1978 paper in Nature is by now a Citation Classic. The 1968 paper by Bushby and Hitchings is the 24th most-cited paper in the British Joumal of Pharmacology and Chemotherapy but that did not become apparent for several years. When citation data are clustered by research specialty, the importance of this work becomes evident. As early as 1973, Elion and Hitchings's work was core to several research fronts. For example, by 1973 the 1968 Bushby/Hitchings paper was already one of three core papers to research front $\$ 73-0582$ on the pharmacokinetics of trimethoprim. In the following section, more of their work will be traced through research-front data from the $S C l$. Figure 1 is indeed an interesting example to contemplate in response to the question about the predictive nature of $\mathrm{ci}$ tation curves.

\section{Research-Front Data}

The significance of the three laureates' work can again be seen in the number and chronological span of ISI ${ }^{\oplus}$ research fronts for which they are core authors. A research front develops when a minimum threshold of authors in a given year cite the same cluster of older papers. Such papers form a natural cluster, to which we assign a research-front name and number. We use these annual fronts to track research activity and trends.

Table 3 presents some of the research fronts in which Black's, Elion's, or Hitchings's works appear as core (cited) documents. The research fronts cover a variety of research on histamine receptors and on antiviral and antibacterial agents, specifically acyclovir and trimethoprim.

The historiographs in Figures 2 and 3 document the development of histamine-2 receptor and antiviral research, respectively, in a more integrated chronological perspective. For example, Black's 1972 paper is core to a string of research fronts from 1973 to the present. Our inventory of research fronts begins in 1970, and we hope to go back even further in the future.

Black's 1972 paper is core to the 1981 research front, "Characterization and function of histamine and histamine receptors" (\#81-0592). A string of research fronts from 1981 to 1983 - all on histamine receptorsleads to a large, coalesced research front in 1984 , "Recent advances in histamine research" (\#84-1155), with 47 core and 612 citing papers. The most recent cluster, formed in 1988, indicates a possible new development in histamine research. Many of the citing papers that form the research front \#88-1256 concern the effects and activity of histamine on the brain, as shown in various animal studies.

Figure 3 traces the development of antiviral research (specifically involving acyclovir) and the Elion-Hitchings connection. Fronts that emerged in 1981 and 1982 show early investigations into this area of pharmacology. Just as in the previous historiograph, these early research clusters all come together in a large 1983 research front, with 47 core and 500 citing papers. Many of the citing papers in front \#83-1973 review the pharmacodynamic properties as well as the clinical uses of acyclovir. Many of the papers specifically report on its efficacy with the herpes simplex virus. Acyclovir research remains dominant in the 1984 research fronts. Then, in 1985, there is a branching off into various areas, including a large cluster of 325 papers ( $\$ 85-1270$ ), describing other acyclic nucleosides for their potential as antiviral agents.

The 1986 research front " Therapeutic use of antiviral agents" ( $\$ 86-1448)$ includes evaluations of new and old antiviral agents. Emerging as a topic among the $\mathbf{4 2 5}$ citing papers is the treatment of AIDS with experimental antiviral drugs. Other papers in this cluster assess antiviral therapy in general. By 1988 the trend that began in 1986 is more obvious. Citing papers in the research front "Ganciclovir therapy" (\$88-0268) deal specifically with the treatment of cytomegalovirus-in both organ transplant and in AIDS cases. Antiviral agents in general, and acyclovir and ganciclovir in particular, are considered. 
Table 3: $S C T^{\circ}$ research fronts from 1973 to 1988 in which papers by J.W. Black, G.B. Elion, or G.H. Hitchings occur as core documents. $A=$ number of core papers. $B=$ number of citing papers.

\begin{tabular}{|c|c|c|}
\hline Number & Name & $\mathbf{A}$ \\
\hline $73-0175$ & Conformation of histamine derivatives & 2 \\
\hline $73-0582$ & Antibacterial activity of trimethoprim and sulfonamides & 3 \\
\hline 74-0175 & Pharmacological characterization of histamine receptors & 4 \\
\hline 74-0518 & Clinical trials of trimethoprim-sulfamethoxazole & 6 \\
\hline $75-0188$ & Histamine and the brain & 3 \\
\hline 75-0553 & Synergy of trimethoprim and sulfamethoxazole & 2 \\
\hline $76-0226$ & Pharmacology and therapeutic use of antihistamines & 5 \\
\hline 77-0295 & Histamine receptor function & 4 \\
\hline $78-0233$ & $\begin{array}{l}\text { Characterization and development of cimetidine as a histamine } \mathrm{H}_{2} \text {-receptor } \\
\text { antagonist }\end{array}$ & 4 \\
\hline $79-0236$ & Histamine receptors & 6 \\
\hline $79-1238$ & Antiherpes compounds & 2 \\
\hline $80-0244$ & Histamine $\mathrm{H}_{2}$-receptors & 5 \\
\hline $80-1109$ & Efficacy of antiherpes agents & 5 \\
\hline $81-0592$ & Characterization and function of histamine and histamine receptors & 7 \\
\hline $81-1273$ & Nucleoside analogs as antiviral agents & 12 \\
\hline $82-0637$ & Clinical applications of histamine receptor antagonists & 9 \\
\hline 82-1043 & Pharmacokinetics of acyclovir & 29 \\
\hline 83-1253 & Histamine and $\mathrm{H}_{2}$-receptor antagonists & 10 \\
\hline $83-1973$ & Clinical uses of acyclovir & 47 \\
\hline 83-3561 & Methylation of methylaminopurines & 3 \\
\hline 83-3868 & Oral antimicrobial dnigs & 3 \\
\hline 84-1155 & Recent advances in histamine research & 47 \\
\hline $84-1302$ & Antiviral activity of acyclovir & 4 \\
\hline 84-1681 & Clinical applications of acyclovir & 42 \\
\hline 84-2442 & Synergistic antiviral activity of acyclovir and other antiviral agents & 2 \\
\hline 84-5778 & Xanthine oxidase activated 6-deoxyacyclovir & 4 \\
\hline $85-0523$ & Activity of histamine $\mathrm{H}_{2}$ antagonists & 14 \\
\hline $85-1216$ & Chemotherapy for herpes simplex infection & 37 \\
\hline $85-1270$ & Conformational features of acyclonucleosides & 35 \\
\hline 85-5189 & Cellular pharmacokinetics of mercaptopurine & 7 \\
\hline $85-5190$ & Antibiotic therapy & 5 \\
\hline $86-0540$ & Pharmacology of histamine $\mathrm{H}_{2}$-receptor antagonists & 10 \\
\hline $86-1448$ & Therapeutic use of antiviral agents & 49 \\
\hline $86-2642$ & Histamine-induced microvascular permeability & 3 \\
\hline $86-3566$ & Clinical pharmacokinetics of trimethoprim & 2 \\
\hline $86-5190$ & Pharmacokinetics of 6-mercaptopurine & 4 \\
\hline $87-1190$ & Histamine $\mathrm{H}_{2}$-receptor antagonists & 12 \\
\hline $87-1468$ & Pharmacological therapy of cytomegalovirus & 53 \\
\hline $88-0268$ & Ganciclovir therapy & 32 \\
\hline $88 \cdot 1256$ & Histamine metabolism in the brain & 16 \\
\hline
\end{tabular}

These historiographs, then, serve to elucidate the links between various areas of research and their development through time.

\section{Biographical Notes}

Sir James W. Black was born in Scotland in 1924. He earned degrees in medicine and surgery (1946) from the University of St. Andrews, UK, where he lectured in physiology. In the late 1950s, he joined Imperial Chemical Industries Limited (ICI LTD), where he worked on propranolol, the wellknown beta blocker. He was with SK\&F from 1964 to 1973 . At SK\&F, as we noted, he developed cimetidine (Tagamet), the highly successful ulcer drug. Black also worked in the Department of Pharmacology, University College London (1973 to 1977), and at Wellcome Research Laboratories, Kent, UK (1978 to 1984). Since 1987 he has headed the research group at the James Black Foundation, London.

Much of Black's research has benefited from his background in medicine and physiology. He has stressed the importance of pharmacological modeling and classification, ${ }^{19}$ as well as of bioassay techniques, ${ }^{6}$ in drug research. Scientists who know him have mentioned his insatiable curiosity and his extreme modesty. (When he received 
Figure 2: Historiograph of research fronts relating to histamine receptors. Numbers of core/citing papers are indicated at the bottom of each box. Asterisks $\left(^{*}\right)$ indicate research fronts in which J.W. Black is a core author.

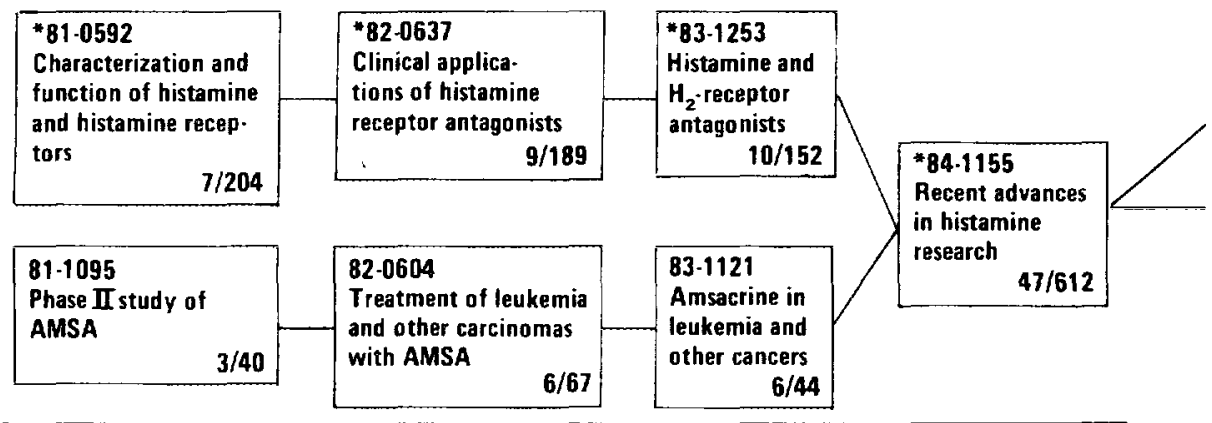

news about the Nobel Prize, he reportedly asked for the beta blocker that won him the prize. 20,21) He was knighted in 1981 and in 1978 received the Mullard Award from the Royal Society, to which he was elected in 1976.

Gertrude B. Elion was born in 1918 in New York City. When she was 15 , her grandfather died of cancer, so she decided to become a scientist. ${ }^{22}$ She graduated from New York University with an MS in 1941. Though she entered a doctoral program at Brooklyn Polytechnic Institute, New York, while working full-time, she never completed the degree. She was required to attend full-time but could not afford to quit her research jobs. Elion did, however, receive three honorary DSc degrees: from Brown University, Providence, Rhode Island, and George Washington University, Washington, DC, in 1969, and from the University of Michigan, Ann Arbor, in 1983.

Elion's is an interesting saga in the history of women in science. She was both a woman and a non-PhD at a time when research laboratories were largely dominated by male doctorates. She worked at many jobs (lab assistant, high-school teacher, food analyst), until she got her lucky break in 1944-with Hitchings. Elion and others claim that she managed to get in only because the war had caused a shortage of men in all fields of work. Although she was once engaged, Elion never married and felt that to have a family and a career would be difficult. 13 This dilemma, which women scientists still confront, has been reviewed in a previous essay. 23

Elion was hired by Hitchings as his lab assistant. She was later promoted to senior research chemist and assistant to the research director. In 1967 she became the head of the Department of Experimental Therapy, where she continued until her retirement as scientist emeritus in 1983.24 According to one account, Hitchings and Elion worked very much collaboratively, due to the nature of the work and of the two scientists themselves. The way Elion describes it: " "He

Figure 3: Historiograph of research on antiviral agents in general and clinical uses of acyclovir in particular. Numbers of core/citing papers are indicated at the bottom of each box. Asterisks $\left(^{*}\right)$ indicate research fronts in which G.B. Elion and/or G.H. Hitchings are core authors.

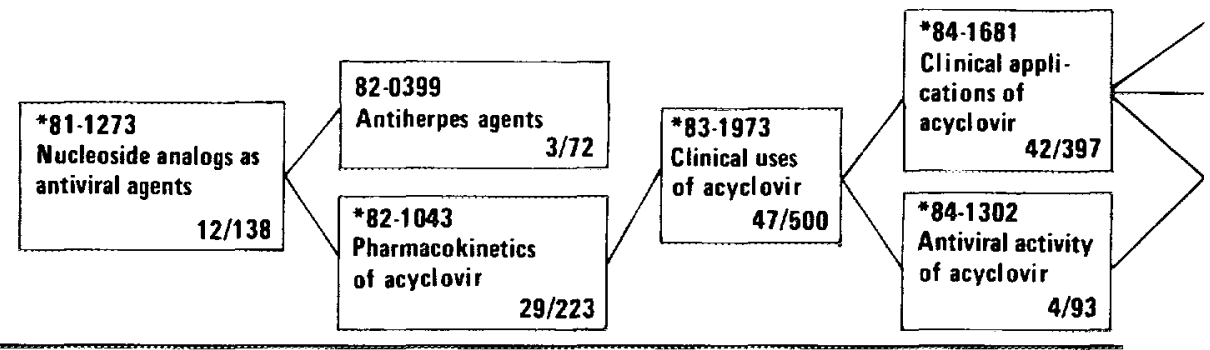




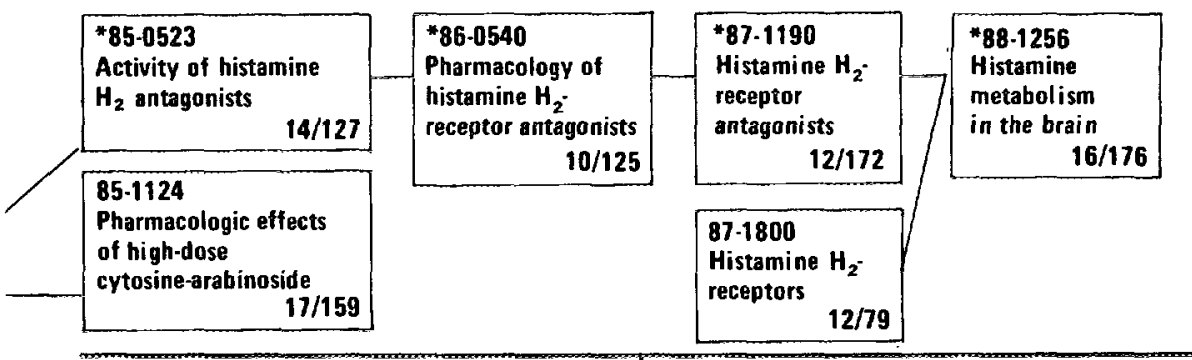

had two arms of research and I was one of them. It wasn't really until he became research director that I was on my own.' ",13 It was a long and fruitful partnership.

Much of the work she did with Hitchings was dominated by the concept of selectivity. That the essence of pharmacology is selectivity of drugs when acting on complex biosystems is an idea that Elion (and, of course, Hitchings) shared with Black. 19,25 This idea, perhaps more than any other, served as a guide through the research Elion conducted so successfully. It is also worth mentioning other characteristics that may have contributed to her successful career. Hitchings, when he first interviewed her, was struck by her intelligence and verve. She is also described by coworkers and other scientists as a born teacher, who delighted in the accomplishments of her junior associates. Indeed, one reporter was told by Elion that she made it a practice not to put her name on published papers simply because the work had been done in her lab-a relatively rare practice in science. 26

Despite drawing attention away from herself, and as the working arm to many of

Hitchings's ideas, Elion had received many awards and honors before the Nobel committee's recognition in October 1988. She remains an active researcher in retirement, while also holding a research professorship at Duke University, Durham, North Carolina, and an adjunct professorship at the University of North Carolina, Chapel Hill. She also holds advisory positions on the National Cancer Advisory Board and on a World Health Organization committee. 24

George H. Hitchings was born in Hoquiam, Washington, in 1905. He received graduate degrees from the University of Washington, Seattle (1928), and Harvard University (1933). After teaching and research at various universities, he joined Burroughs Wellcome in 1942. There he pursued a very active and, many deem, brilliant career in pharmacological research until his retirement in 1975. Much of his time now goes into philanthropy as a founder of the Greater Triangle Community Foundation, made up of many charities, and as president of the Burroughs Wellcome Fund, a philanthropic trust supported by the Burroughs Wellcome Company that subsidizes under-

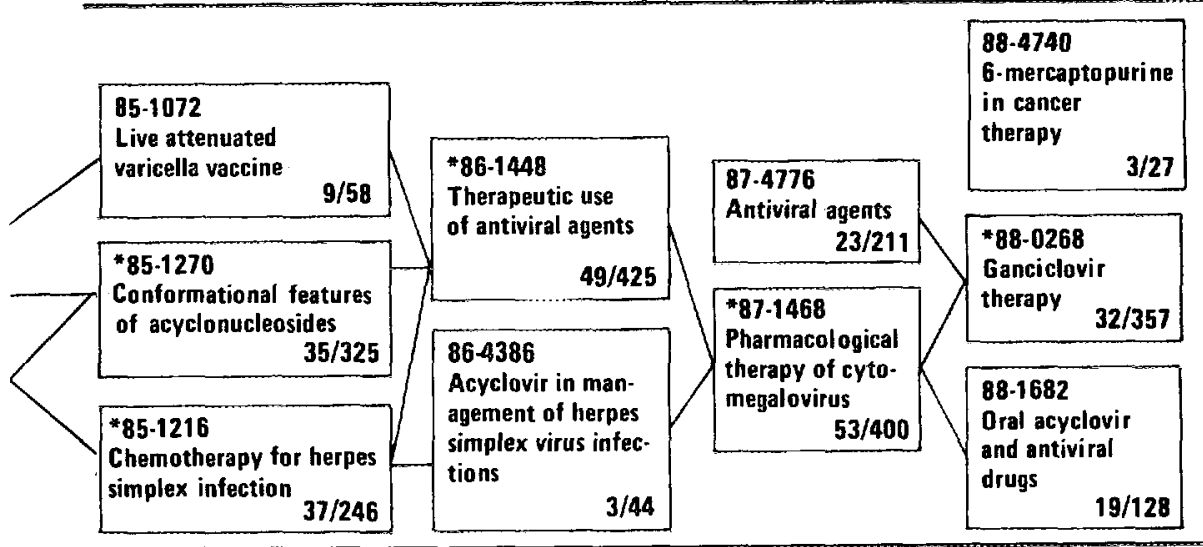


financed aspects of medical research. Hitchings is also a director of the Durham Chapter of the American Red Cross (which will name its new building after him), of the Life Science Research Foundation, and of the Royal Society of Medicine Foundation.

Hitchings has received many other distinguished awards through the years, including the Gairdner Foundation International Award in 1968, the Robert de Villier Scientific Award from the Leukemia Society of America and the Passano Award in 1969, the Cameron Prize in Practical Therapeutics from the University of Edinburgh in 1972, and the Bertner Foundation Award in 1974. $\mathrm{He}$ also received honorary doctorates from the University of Michigan (1971), the University of Strathclyde, Glasgow, UK (1977), Emory University, Atlanta, Georgia (1981), and Duke University (1982), among others. In 1974 Hitchings was elected a foreign member of the Royal Society of London. He is also a member of the National Academy of Sciences (US) and an Honorary Fellow of the Royal Society of Medicine and the Royal Society of Chemistry.

Finally, a word needs to be said about the Burroughs Wellcome Foundation, where all three of the Nobel scientists have worked. Black worked for about six years as director of therapeutic research at Wellcome Research Laboratories (in the UK); and, as mentioned earlier, Elion and Hitchings each worked at Burroughs Wellcome in the US for some 40 years. Apparently the atmosphere at this institution has been conducive to discovery. As noted in an earlier essay about Sir Henry Wellcome and his institution, ${ }^{27}$ the trust fund in his will was stipulated for use in the advancement of research "which may conduce to the improvement of the physical conditions of mankind." 28

This indeed has been the mission of these and other scientists who have worked there. As many scientists have noted in interviews, the company fosters an atmosphere of freedom to follow their thoughts wherever they lead. ${ }^{29}$ It is not coincidental that all three scientists were able to follow up on their bold and original ideas, which were in part the reason for their successful drug discoveries.
That this institution has played a significant role in the advancement of medicinal science can further be attested by other Nobel Prize winners. In 1936 Sir Henry Dale, an early director of research, won the Nobel Prize for his studies of chemical transmission of nerve impulses. In 1982 the prize was awarded to Vane, then group research and development director, for his role in discovering how aspirin works to reduce inflammation and pain. ${ }^{3}$

\section{Conclusion}

These three laureates have worked tirelessly to produce drugs for serious diseases. The impact of their work is undeniable. For example, Black's beta blocker is reportedly currently taken by five million people, 21 and Elion and Hitchings's earlier discoveries with mercaptopurine are said to have resulted in 80 percent cure rates in leukemic patients today. ${ }^{29}$ The three also shared the same philosophy-often referred to as the "rational approach" and "enlightened empiricism"- of designing new drugs by analyzing the chemistry of the body. In other words, though their work is essentially on the practical side of science, it evolved from their accumulated knowledge of the way cells operate. As mentioned earlier, both teams, on either side of the Atlantic, believed that the principle of drug selectivity held the key.

Even though their colleagues were aware of both their methodology and their drug designs all along, one may wonder why it took the Nobel committee decades to acknowledge their discoveries. According to Folke Sjoqvist, professor of clinical pharmacology at the Karolinska Institute, the reason appears to be that the committee wanted to evaluate the long-term benefits and hazards of the drugs. 10

It may be appropriate to end with a quotation that eloquently states the work philosophy of this year's three laureates, from their senior member. Quoting himself, Hitchings concluded a speech he presented to the American Association for Cancer Research in 1984 thus: 
Empirical methods continue to prevail wherever complexity is too great for analysis, but pure empiricism is self-limiting. The purposeful exploration of enzymes, metabolic pathways and cell receptors, on the other hand, leads to increasing competence. The tools that had to be invented for one purpose are frequently applicable to the next with only minor modification. Competence accumulates, and so does one's confidence that the future will bring the solution of many problems that at present seem difficult or insoluble. 30

My thanks to C.J. Fiscus and Sanaa Shar. noubi for their help in the preparation of this essay,

\section{REFERENCES}

1. Karolinska Institute. Nobel Assembly. Press release. 17 October 1988,8 p.

2. Zuckerman H. Scientific elite: Nobel laureates in the United States. New York: Free Press, 1977. $335 \mathrm{p}$.

3. Garfield E. The 1982 Nobel Prize in medicine recognizes the impact of prostaglandin research by S.K. Bergström, B.I. Samuelsson, and J.R. Vane. Essays of an information scientist: the awards of science and other essays. Philadelphia: ISI Press, 1985. Vol. 7. p. 77-86.

4. Bovet, Daniel. (Wasson T, ed.) Nobel Prize winners. New York: Wilson, 1987. p. 130-2.

5. Ahlquist R P. A study of the adrenotropic receptors. Amer. J. Physiol. 153:586-600, 1948.

6. Black J W. Drugs from emasculated hormones: the principle of syntopic antagonism. Stockholm, Sweden: Nobel Foundation, 1989, 32 p. (Nobel lecture.)

7. Black J W, Duncan W A M, Durant C J, Ganellin C R \& Parsons E M. Definition and antagonism of histamine $\mathrm{H}_{2}$-receptors. Nature 236:385-90, 1972.

8. Garfleld E. All about ulcers, antacids, and how little we know, Op. cit., 1981. Vol 4. p. 666-73. (Reprinted from: Current Contents (45):5-12, 10 November 1980.)

9. -......... Since 1816 the John Scott and other Philadelphia awards have recognized "useful" scientific discoveries-James Black and Benjamin Rubin head a list of recent distinguished recipients. Ibid., 1983.Vol. 5. p. 686-94.

10. Altman L K. 3 drug pioneers win Nobel in Medicine. New York Times 18 October 1988. p. Al; C17.

11. Schaeffer H J, Beauchamp L, de Miranda P, Elion G B, Bauer D J \& Collins P. 9-(2-hydroxyethoxymethyl)guanine activity against viruses of the herpes group. Nature 272:583-5, 1978.

12. Elion G B, Furman P A, Fyfe J A, de Miranda P, Beauchamp L \& Schaeffer $\mathbf{H}$ J. Selectivity of action of an antiherpetic agent, 9-(2-hydroxyethoxymethyl)guanine. Proc. Nas. Acad. Sci. USA 74:5716-20, 1977.

13. Bouton K. The Nobel pair. New York Times Mag. 29 January 1989. p. 28-9; 60; 82; 86-8.

14. Garfield E. Journal citation studies. VIII. Some highly cited articles from highly cited general medical and clinical journals. Op. cit., 1977. Vol. 2. p. 86-93. (Reprinted from: Current Contents (27):5-12, 3 July 1974.)

15. - 100 classics from The Lancet. Bid., 1985. Vol. 7. p. 295-305.

16. an............ The 1972 articles most frequently cited in the years 1972-1975. Boid., 1977. Vol. 2. p. 474-8.

17. - The articles most cited in 1961-1982. 3. Another 100 all-time Citation Classics. Ibid., 1985. Vol. 7. p. $270-6$.

18. Bushby $S \mathbf{R}$ M Hitchings $G$ H. Trimethoprim, a sulphonamide potentiator. Brit. J. Pharmacol. Chemother. 33:72-90, 1968.

19. Black J W. Pharmacology: analysis and exploration. Brit. Med. J. 293:252-5, 1986.

20. Schmeck H M. A pharmacology pioneer who avoids the spotlight. New York Times 18 October 1988. p. C16.

21. Gerber L. 3 researchers win Nobel in medicine. Philadelphia Inquirer 18 October 1988. p. A1; A16.

22. Kolata G. A research collaboration spanning four decades. New York Times 18 October 1988. p. C16.

23. Garfield E. Why aren't there more women in science? Op. cit., 1983. Vol. 5. p. 498-505.

24. Burroughs Wellcome. Gertrude B. Elion. October 1988. 2 p. (Press release.)

25. Elion G B. Selectivity-key to chemotherapy: presidential address. Cancer Res. 45:2943-50, 1985.

26. Garfield E. Citation behavior-an aid or a hindrance to information retrieval? Current Contents (18):3-8, I May 1989.

27. -..... The enduring legacy of Sir Henry Wellcome-pharmaceutical entrepreneur, philanthropist, and collector extraordinaire. Current Contents (3):3-8, 18 January 1988.

28. Turner H. Henry Wellcome: the man, his collection and his legacy. London: Heinemann, 1980. p. 79.

29. Burroughs Wellcome. Burroughs Wellcome scientists emeriti share Nobel Prize in Medicine. October 1988. 4 p. (Press release.)

30. Hitchings G H \& Elion G B. Layer on layer: the Bruce F. Cain Memorial Award lecture. Cancer Res. 45:2415-20, 1985. 